\title{
NITROGEN FERTILIZATION FOR THE NURSERY PRODUCTION OF AUSTRALIAN RED CEDAR
}

\author{
Júlio Rieger Lucchese ${ }^{1 *}$, Marília Lazarotto ${ }^{2}$, Marcio Alberto Hilgert ${ }^{3}$, Claudimar Sidnei Fior ${ }^{4}$, Larissa Campos \\ de Sá ${ }^{5}$, Carolina Brito Brose ${ }^{6}$ \\ ${ }^{1 *}$ Universidade Federal do Rio Grande do Sul, Programa de Pós-graduação em Fitotecnia, Faculdade de Agronomia, Av. Bento Gonçalves, \\ 7712, CEP 91540-000, Porto Alegre, RS, Brazil. juliolucchese@ufrgs.br (*AUTOR PARA CORRESPONDÊNCIA) \\ ${ }^{2}$ Universidade Federal do Rio Grande do Sul, Departamento de Horticultura e Silvicultura, Faculdade de Agronomia, Av. Bento Gonçalves, \\ 7712, CEP 91540-000, Porto Alegre, RS, Brazil. marilia.lazarotto@ufrgs.br \\ ${ }^{3}$ Universidade Federal do Rio Grande do Sul, Curso de Agronomia, Faculdade de Agronomia, Av. Bento Gonçalves, 7712, CEP 91540-000, \\ Porto Alegre, RS, Brazil. marcioahilgert@yahoo.com.br \\ ${ }^{4}$ Universidade Federal do Rio Grande do Sul, Departamento de Horticultura e Silvicultura, Faculdade de Agronomia, Av. Bento Gonçalves, \\ 7712, CEP 91540-000, Porto Alegre, RS, Brazil. csfior@ufrgs.br \\ ${ }^{5}$ Universidade Federal do Rio Grande do Sul, Curso de Agronomia, Faculdade de Agronomia, Av. Bento Gonçalves, 7712, CEP 91540-000, \\ Porto Alegre, RS, Brazil. desa_larissa@hotmail.com \\ ${ }^{6}$ Universidade Federal do Rio Grande do Sul, Curso de Agronomia, Faculdade de Agronomia, Av. Bento Gonçalves, 7712, CEP 91540-000, \\ Porto Alegre, RS, Brazil. carolbbrose@gmail.com
}

Recebido para publicação: 12/04/2018 - Aceito para publicação: 31/10/2018

\begin{abstract}
Resumo
Adubação nitrogenada na produção de mudas de cedro-australiano. A adubação é uma das práticas culturais mais importantes na produção de mudas, influenciando significativamente na qualidade e no estabelecimento de novos povoamentos. Como a produção de mudas de Toona ciliata var. australis carece de informações sobre sua exigência nutricional, em especial o nitrogênio, esse trabalho avaliou o efeito de diferentes concentrações de nitrogênio e intervalos de aplicações na produção de mudas dessa espécie, determinando a concentração mais apropriada. As mudas foram adubadas com 0, 250, 500, 1000, 2000 e $4000 \mathrm{mg} \mathrm{L}^{-1}$ de nitrogênio (N), em intervalos de 7 e 14 dias até o final do experimento. Foram observados incrementos em altura, diâmetro, massa seca da parte aérea e raiz, e índice de qualidade de Dickson conforme o aumento da concentração e decaindo em concentrações mais altas, resultando em uma regressão quadrática negativa em todas as variáveis, exceto na relação de altura e diâmetro, a qual aumentou conforme a concentração de $\mathrm{N}$ aumenta. O maior crescimento observado pelo índice de qualidade de Dickson foi obtido utilizando a concentração de $2060 \mathrm{mg} \mathrm{L}^{-1}$. A ausência de nitrogênio e a concentração de $4000 \mathrm{mg} \mathrm{L}^{-1}$ limita o desenvolvimento das mudas, independente do intervalo. Recomenda-se então a utilização de $2060 \mathrm{mg} \mathrm{L}^{-1}$ a cada 7 dias para a produção de mudas de Toona ciliata var. australis.
\end{abstract}

Palavras-chave: índice de Dickson, recomendação de fertilização, Toona ciliata, viveiro.

\section{Abstract}

Fertilization is one of the most important cultural practices in the production of seedlings, significantly influencing the quality and establishment of new stands. As the production of Toona ciliata var. australis lacks information on their nutritional requirements, especially nitrogen, this work evaluated the effect of different nitrogen concentrations and application intervals on the production of seedlings of this species, determining the most appropriate concentration. The seedlings were fertilized with $0,250,500,1000,2000$ and $4000 \mathrm{mg} \mathrm{L}^{-1}$ of nitrogen $(\mathrm{N})$, at intervals of 7 and 14 days till the end of the experiment. Increases in height, diameter, dry shoot and root mass, and Dickson quality index were observed as the concentration increased and decreased in higher concentrations, showing a negative quadratic regression in all variables, except the height/diameter ratio, which showed a higher value as $\mathrm{N}$ concentration increases. A higher growth showed by the Dickson quality index was achieved using the concentration of $2060 \mathrm{mg} \mathrm{L}^{-1}$. The absence of nitrogen and the concentration of $4000 \mathrm{mg} \mathrm{L}$ ${ }^{1}$ limits the development of the seedlings, regardless of the interval. It is therefore recommended to use 2060 $\mathrm{mg} \mathrm{L}^{-1}$ every 7 days for the production of Toona ciliata var. australis.

Keywords: Dickson quality index, fertilization recommendation, seedlings, Toona ciliata.

\section{INTRODUCTION}

Seedlings production is an important stage of silviculture, because it increases the chances of success in the establishment of forestry stands, due to higher quality of the plants (VILLAR-SALVADOR et al., 2004; CAIONE et al., 2012). Many factors involved in this stage significantly influence the growth, quality and the performance of seedlings in the field right after planting; however, only a few can be controlled by nurserymen

FLORESTA, Curitiba, PR, v. 49, n. 3, p. 431 - 438, jul/set 2019

Lucchese, J. R. et.al.

ISSN eletrônico 1982-4688

DOI: $10.5380 /$ rf.v49 i3.58905 
(GROSSNICKLE 2012; AKPO et al., 2014). Type of fertilization, container and substrate are factors that have been studied for the production of seedlings of several forest species, such as Cedrela fissilis Vell. (OLIVEIRA et al., 2008; ANTONIAZZI et al., 2013) and Toona ciliata M. Roem. (MORETTI et al., 2011; CALDEIRA et al., 2012; LISBOA et al., 2012; SOMAVILLA et al., 2014).

After irrigation, fertilization is the most important cultural practices in nursery production, because it controls both the rate and the type of seedling growth (LANDIS, 1989), influencing their quality (FONSECA et al., 2006; SOMAVILLA et al., 2014). Since each specie has different nutritional requirements for each nursery stage (establishment, rapid growth and hardening phase) (LANDIS, 1989), the nurseryman must be aware of the source and dosages of nutrients, as well as the intervals of fertilization applications. In several forest species, an increase of seedlings quality has been observed after changes in the fertilization programs (FONSECA et al., 2006; CAIONE et al., 2012; SOMAVILLA et al., 2014), emphasizing the importance of this practice.

As fertilization programs include several nutrients, determine the concentration for each nutrient at each stage and for each species is an arduous task. Most programs rely primarily on the nitrogen concentration to determine the amount of other nutrients, since $\mathrm{N}$ is the most limiting nutrient of plant growth in containers (LANDIS, 1989). The amino acids development depends on nitrogen and its lack can lead to failures in the chlorophyll and cytochromes production, resulting in leaves with chlorosis (GREBNER et al., 2013). Moreover, nitrogen omission or reduction causes several negative changes in the morphological characteristics directly linked to seedling quality (WEBB et al., 1997; MORETTI et al., 2011). In contrast, high doses of nitrogen at the nursery stage increase the stomatal conductance of the seedlings, reducing their tolerance to drought after planting (VILLAR-SALVADOR et al., 2005; TRUBAT et al., 2008). Therefore, the nutrient dosage should be adequate for the seedlings production, that is, in balance with the plant growth and respecting quality indexes.

T. ciliata var. australis (Meliaceae family) presents a wood production with great economic value (BYGRAVE; BYGRAVE, 2005). Several studies have aimed to improve the seedling quality (MORETTI et al., 2011, 2012; CALDEIRA et al., 2012; LISBOA et al., 2012; SOMAVILLA et al., 2014; LIMA et al., 2015; MELO BRAGA et al., 2015), however, the production of $T$. ciliata var. australis seedlings still faces problems regarding the nutritional requirements, especially for nitrogen, which is one of the most required elements for its growth (MORETTI et al., 2011). Thus, the objective of this study was to evaluate the effect of different nitrogen concentrations and application intervals on the seedlings production of this species, determining the most appropriate concentration for seedlings development.

\section{MATERIALS AND METHODS}

The experiment was conducted in the greenhouse of the Department of Horticulture and Forestry of the Federal University of Rio Grande do Sul (UFRGS), in the city of Porto Alegre. The seeds were obtained from an accredited company in RENASEM (BA-01048/2011), collected in a Seed Production Area in Viçosa (state of Minas Gerais) from selected trees in a 10 ha of radius. These seeds had an average germination of $86 \%$ and were stored in a cold chamber at $5^{\circ} \mathrm{C}$. Before sowing, the seeds were disinfested in $70 \%$ alcohol for 30 seconds and $1 \%$ $\mathrm{NaOCl}$ for 60 seconds, followed by a washing step in sterilized water for 60 seconds, and then placed on filter papers for surface drying and transported to the greenhouse to be sowed.

The seeds were sowed in January 2016, with three seeds (average) per container of $55 \mathrm{~cm}^{3}$. Carolina Soil substrate was used; according to the manufacturer's information, the substrate had a $\mathrm{pH}$ of $5.5 \pm 0.5$, electrical conductivity 1:5 ratio of $0.4 \pm 0.3 \mathrm{mS} \mathrm{cm}^{-1}$, composed of Sphagnun peat, expanded vermiculite, dolomitic limestone, agricultural gypsum and traces of NPK fertilizer. Irrigation was carried out twice a day, for 10 minutes each time, presenting $\mathrm{pH}$ and an electrical conductivity average of 6.54 and $130.9 \mu \mathrm{S} . \mathrm{cm}^{-1}$, respectively.

The seedlings were thinned 30 days after sowing, keeping only one per container, selecting only those with higher height or located closer to the container central position.

Fourteen days after thinning, the height and diameter of the seedlings $(4.1 \mathrm{~cm}$ and $1.1 \mathrm{~mm}$, respectively) was measured. At this time the fertilization program was started, with a solution composed by: $480 \mathrm{mg} \mathrm{L} \mathrm{KH}_{2}^{-1} \mathrm{PO}_{4}$, $650 \mathrm{mg} \mathrm{L}^{-1} \mathrm{KCl}, 400 \mathrm{mg} \mathrm{L}^{-1} \mathrm{MgSO}_{4} .7 \mathrm{H}_{2} \mathrm{O}$ and $917 \mathrm{mg} \mathrm{L}^{-1} \mathrm{CaCl}_{2} \cdot 2 \mathrm{H}_{2} \mathrm{O}$. For the treatments, the compound $\mathrm{NH}_{4} \mathrm{NO}_{3}$ was used to obtain different concentrations of nitrogen $\left(0,250,500,1000,2000\right.$ and $\left.4000 \mathrm{mg} \mathrm{L}^{-1}\right)$. The fertilizer was applied every 7 and 14 days till the end of the experiment, wherein each seedling received $5 \mathrm{~mL}$ of the solution per application. These two intervals were chosen for being the most common in greenhouse operations. As fertilization control, the $\mathrm{pH}$ and electrical conductivity of the substrate were monitored with a PourThru test every 14 days. Around each repetition, an outside line was maintained without application of the fertilization treatment in order to soften the border effect. 
The shoot height (from substrate level to the last leaf insertion) and the collar diameter were measured 130 days after sowing, with a millimeter ruler and a digital caliper. Then, the seedlings were gently pulled off the containers, and their roots were washed off under tap water removing the maximum amount of substrate.

The shoots and the roots were separated at the base and weighed in a semi-analytical balance, recording its fresh mass ( $\mathrm{g}$ seedling ${ }^{-1}$ ). Afterwards, the samples were dried in oven at $65{ }^{\circ} \mathrm{C}$ until constant weight, and then reweighed in a semi-analytical balance to register the dry mass ( $\mathrm{g}$ seedling $\left.{ }^{-1}\right)$. With these data the following ratios were calculated: relationship between the shoot height $(\mathrm{cm})$ and diameter $(\mathrm{mm})$ (RHD) and Dickson quality index (DQI) according Dickson et al. (1960):

$$
\mathrm{DQI}=\frac{\mathrm{SDM}(\mathrm{g})+\mathrm{RDM}(\mathrm{g})}{\frac{\mathrm{H}(\mathrm{cm})}{\mathrm{D}(\mathrm{cm})}+\frac{\mathrm{SDM}(\mathrm{g})}{\mathrm{RDM}(\mathrm{g})}}
$$

In which: $\mathrm{SDM}=$ shoot dry mass; $\mathrm{RDM}=$ root dry mass; $\mathrm{H}=$ shoot height; $\mathrm{D}=$ collar diameter.

The experiment design was completely randomized, arranged in a $2 \times 5$ factorial experiment (application interval $\times$ nitrogen concentrations), with each treatment consisting of four replicates with 8 plants each. Residual normality and homogeneity of variances were verified using the Shapiro-Wilk and Bartlett tests, respectively. The data were submitted to analysis of variance and polynomial regression. All the analyses and graphs were performed using the RStudio software (version 1.0.136).

\section{RESULTS}

The increase in nitrogen concentration provided an increase in height, with the exception of the concentration of $4000 \mathrm{mg} \mathrm{L}^{-1}$ dispensed every 7 days (Figure $1-\mathrm{A}$ ). The seedlings under the 7 days interval grew two times higher using $2000 \mathrm{mg} \mathrm{L}^{-1}(17.1 \mathrm{~cm})$ when compared to $0 \mathrm{mg} \mathrm{L}^{-1}(8.4 \mathrm{~cm})$. The regression analysis estimated a maximum growth of $18.4 \mathrm{~cm}$ using a nitrogen concentration of $2456 \mathrm{mg} \mathrm{L}^{-1}$ every 7 days, or $17.8 \mathrm{~cm}$ using a concentration of $3326 \mathrm{mg} \mathrm{L}^{-1}$ every 14 days.
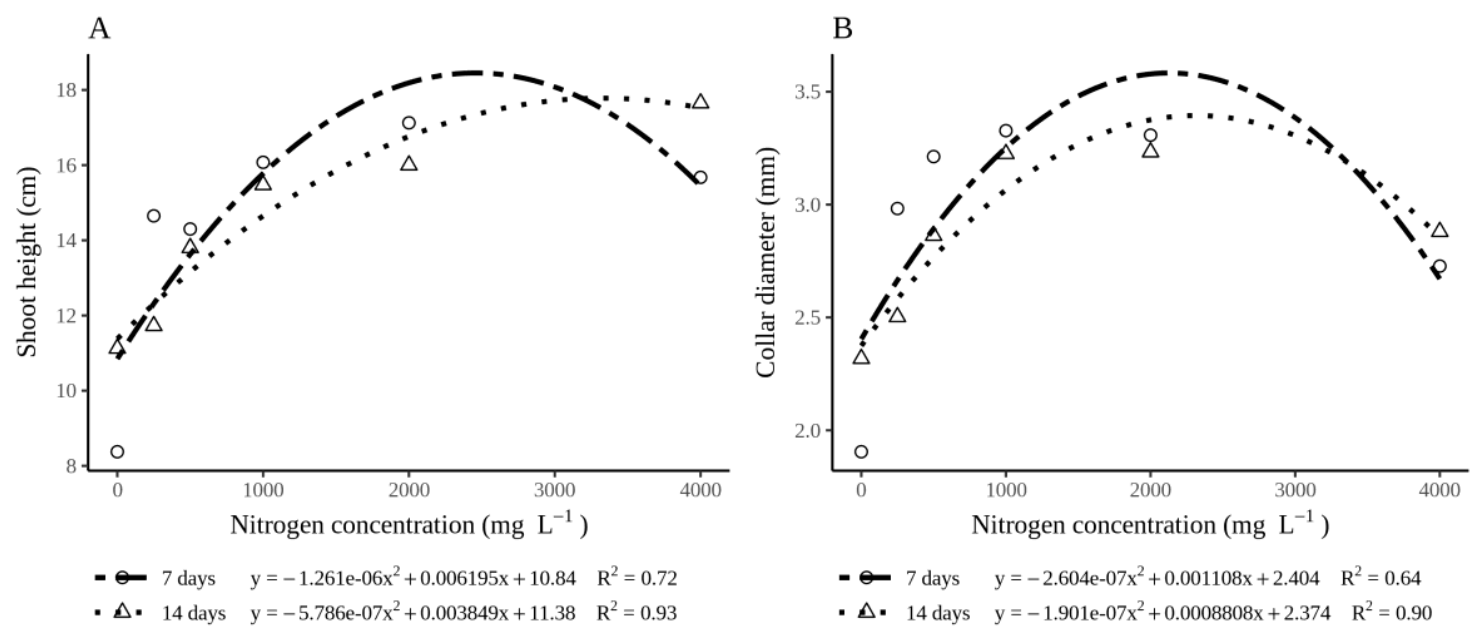

Figure 1. Relationship between nitrogen concentrations and shoot height (A) and the collar diameter (B) of Toona ciliata var. australis seedlings after 130 days after sowing in greenhouse.

Figura 1. Relação entre a concentração de nitrogênio e altura da parte aérea (A) e o diâmetro do coleto (B) de mudas de Toona ciliata var. australis após 130 dias da semeadura em casa de vegetação.

Similar to the height, growth of the collar diameter was limited at the nitrogen concentration of $4000 \mathrm{mg}$ $\mathrm{L}^{-1}$, independently from the application interval (Figure $1-\mathrm{B}$ ). Under the 7 days interval application, the collar diameter can have a maximum value of $3.6 \mathrm{~cm}$ using $2127 \mathrm{mg} \mathrm{N}^{-1}$, and under 14 days interval a value of $3.4 \mathrm{~cm}$ using $2317 \mathrm{mg} \mathrm{N}^{-1}$.

The shoot dry mass (Figure 2 - A) increased at low nitrogen concentrations up to $2000 \mathrm{mg} \mathrm{L}^{-1}$, decreasing in the concentration of $4000 \mathrm{mg} \mathrm{L}^{-1}$, with the 7 day interval application being greater at almost all concentrations, wherein the maximum value was $1.2 \mathrm{~g}$ using $2267 \mathrm{mg} \mathrm{N}^{-1}$. The 14 day interval showed a maximum value of $0.9 \mathrm{~g}$ using $2715 \mathrm{mg} \mathrm{N}^{-1}$.

FLORESTA, Curitiba, PR, v. 49, n. 3, p. 431 - 438, jul/set 2019.

Lucchese, J. R. et.al.

ISSN eletrônico 1982-4688

DOI: $10.5380 /$ rf.v49 i3.58905 

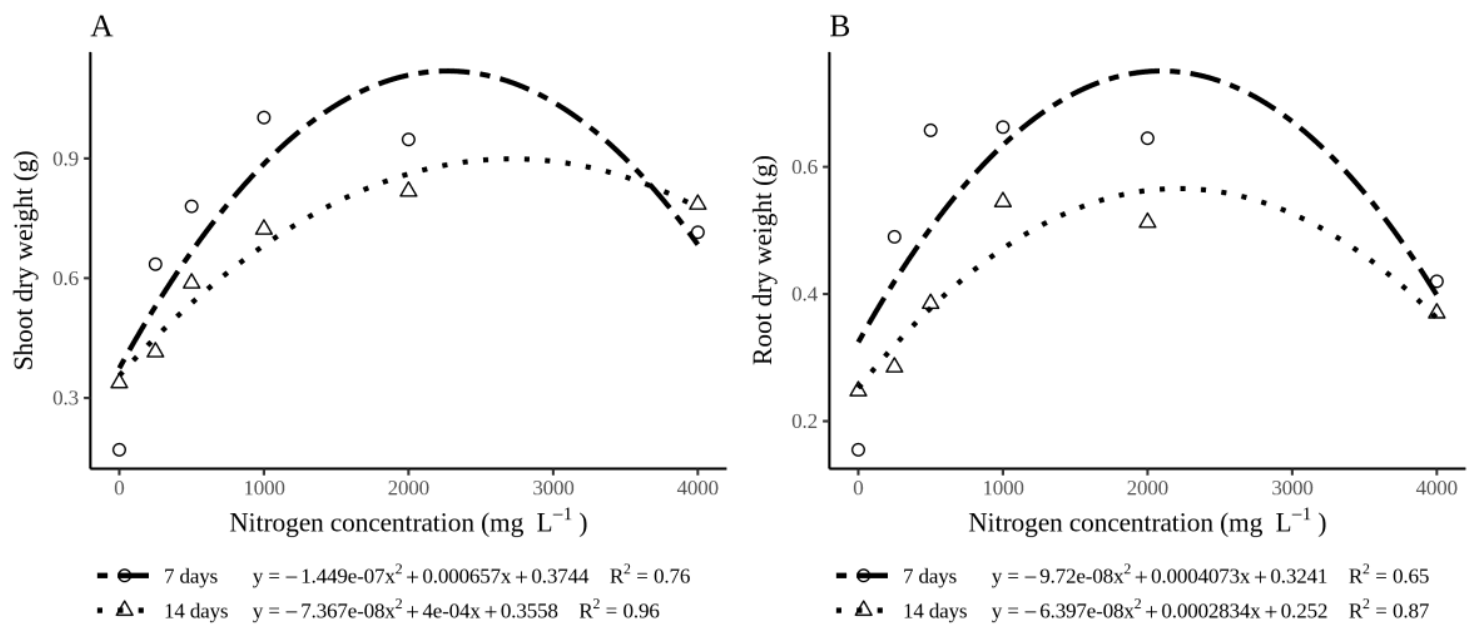

Figure 2. Relationship between nitrogen concentrations and shoot dry weight (A) and root dry weight (B) of Toona ciliata var. australis seedlings after 130 days after sowing in greenhouse

Figura 2. Relação entre a concentração de nitrogênio e a massa seca da parte aérea (A) e massa seca da raiz (B) de mudas de Toona ciliata var. australis após 130 dias da semeadura em casa de vegetação.

For the root dry mass, the two intervals showed a quadratic behavior, however, the interval of 7 days was greater in almost all concentrations. There was a greater production of root dry mass with nitrogen concentration of $2095 \mathrm{mg} \mathrm{L}^{-1}$ applied every 7 days $(0.75 \mathrm{~g})$, whereas the concentration of $4000 \mathrm{mg} \mathrm{L}^{-1}$ limited the increment of the mass, regardless of the application interval. Under a 14 day interval, the maximum value was found to be 0.56 $\mathrm{g}$ at $2215 \mathrm{mg} \mathrm{N}^{-1}$.

DQI had a significant effect on the interaction between interval and concentration (Figure 3). Both intervals presented quadratic behavior, however, the DQI with fertilizations every 7 days showed a higher value in most concentrations when compared to 14 days. A maximum DQI of 0.29 for 7 days was estimated at $2060 \mathrm{mg}$ $\mathrm{L}^{-1}$ of nitrogen concentration and 0.22 for 14 days at $2190 \mathrm{mg} \mathrm{L}^{-1}$.

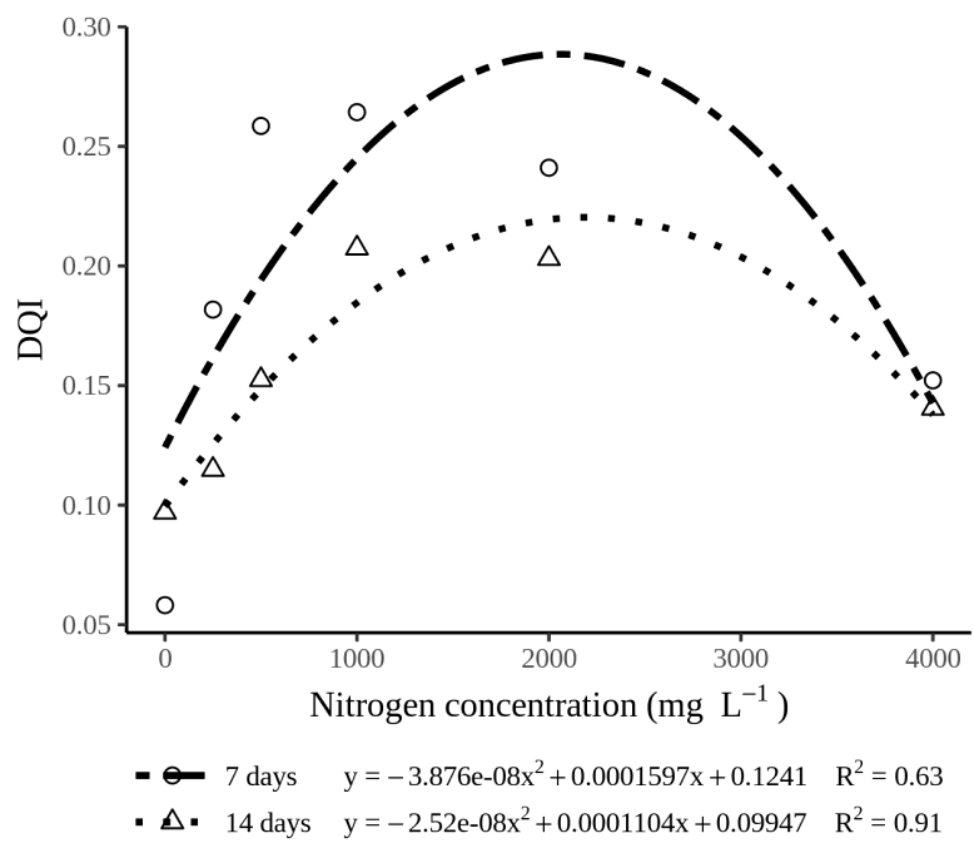

Figure 3. Relationship between nitrogen concentrations and Dickson Quality Index (DQI) of Toona ciliata var. australis seedlings after 130 days after sowing in greenhouse.

Figura 3. Relação entre a concentração de nitrogênio e o Índice de qualidade Dickson (DQI) de mudas de Toona ciliata var. australis após 130 dias da semeadura em casa de vegetação. 
For the RHD variable, only an effect due to different $\mathrm{N}$ concentrations was observed, without interaction or effect based on the intervals (Figure 4). RHD increased proportional to the increase of N concentrations, presenting a positive quadratic behavior, due to the greater increment in height in respect to the diameter, resulting in tall but fine seedlings.

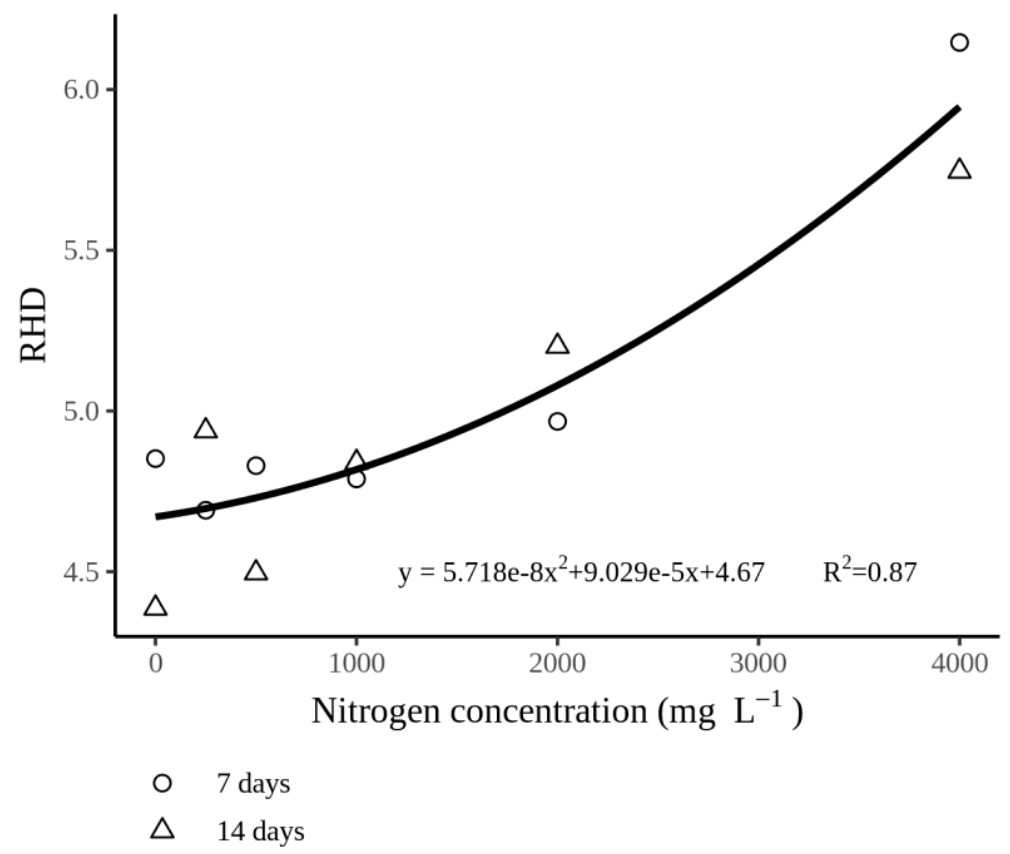

Figure 4. Shoot height $(\mathrm{cm})$ and base diameter (mm) ratio (RHD) of Toona ciliata var. australis seedlings after 130 days after sowing in greenhouse under different nitrogen concentrations and fertilization interval and fertilization interval.

Figura 4. Relação da razão altura da parte aérea $(\mathrm{cm})$ e diâmetro (mm) (RHD) de mudas de Toona ciliata var. australis após 130 dias da semeadura em casa de vegetação e submetidas a diferentes concentrações de nitrogênio e intervalos de adubação.

\section{DISCUSSION}

At the end of the 130 day period, the total dosage applied under 7 days interval fertilization at $4000 \mathrm{mg}$ $\mathrm{L}^{-1}$ was $72000 \mathrm{mg}$ of $\mathrm{N}$. As for the fertilization of $2000 \mathrm{mg} \mathrm{L}^{-1}$, the total was $36000 \mathrm{mg}$ for the 7 days interval and $18000 \mathrm{mg}$ for the 14 days interval, that is, the total dosage of each fertilization every 7 days corresponds to twice the fertilization of 14 days. This fact can justify the greater development and growth of the seedlings with the short interval.

Similar to our work, Caldeira et al. (2012) found out that higher shoot heights were obtained for substrates with a higher proportion of biosolids, which, among the substrates tested in their work, were also the one with the highest concentration of $\mathrm{N}$. The shoot heights obtained with a higher proportion of biosolids were similar to those observed for seedlings submitted to a nitrogen concentration of $2000 \mathrm{mg} \mathrm{L}^{-1}$ for 7 days and $4000 \mathrm{mg} \mathrm{L}^{-1}$ for 14 days. However, Lima et al. (2015), with only one application of nitrogen fertilization, obtained seedlings with an average shoot height higher than those found in this study, which may be related to the fact that the authors used larger containers $\left(3 \mathrm{dm}^{3}\right)$, and according to Lisboa et al. (2012), T. ciliata var. australis is very responsive to the volume of the container. The shoot height is correlated to the leaves number, and therefore, it is considered a good estimator of photosynthetic capacity and area of transpiration (LANDIS et al., 2010).

The nitrogen concentrations of 1000 and $2000 \mathrm{mg} \mathrm{L}^{-1}$, regardless the interval used, increased the seedlings growth to a diameter greater than $3 \mathrm{~mm}$, considered a minimum standard for planting T. ciliata var. australis on the field (VILELA; STEHLING, 2015). Despite this, the results found in this study were much lower than those of Caldeira et al. (2012), who kept the seedlings for a longer period in the nursery (180 days after sowing), thus, being a probable reason for the greater diameter development.

The highest nitrogen concentration $\left(4000 \mathrm{mg} \mathrm{L}^{-1}\right)$ limited the seedlings growth in all variables and intervals tested, except for shoot height at 14 days, in which the seedlings were taller but thinner. This limited

FLORESTA, Curitiba, PR, v. 49, n. 3, p. 431 - 438, jul/set 2019.

Lucchese, J. R. et.al.

ISSN eletrônico 1982-4688

DOI: $10.5380 /$ rf.v49 i3.58905 
growth can be caused due to the toxic effect of the concentration used. According to Landis (1989), the toxic effect occurs precisely when there is a decrease in growth, which can even lead to the seedlings tissues death in extreme cases. Seedlings of Samanea inopinata (Harms) Ducke fertilized with different doses of ammonium sulfate every 14 and 28 days also showed a negative effect at higher doses, being more pronounced in the shortest application intervals of fertilization (FONSECA et al., 2006).

The fertilization with $0 \mathrm{mg} \mathrm{L}^{-1}$ of $\mathrm{N}$ was the one that most limited the mass production, both for the shoot and for the root. This was observed by Webb et al. (1997), where the omission of $\mathrm{N}$ severely reduced the mass of T. ciliata seedlings, in addition to presenting symptoms of chlorosis in every plant. According to these authors, apparently there was also growth limitation in the absence of $\mathrm{P}, \mathrm{K}$ and $\mathrm{S}$. For T. ciliata var. australis seedlings, the omission of nitrogen causes several negative morphological changes (MORETTI et al., 2011), decreasing the dry mass production (WEBB et al., 1997).

Being a primary macronutrient and the most required nutrient for plant growth, the absence of nitrogen have an important effect on photosynthesis and biomass production (PESSARAKLI, 2016). The application of nitrogen helped the $T$. ciliata seedlings to synthetize more carbohydrates due to the higher activity of photosynthesis, which was represented by the higher amount of dry mass found in this work.

The dry root mass can have an important impact after field planting, wherein seedlings with a greater amount of dry root mass may have a higher chance of survival, due to greater tolerance to drought (GROSSNICKLE, 2012). However, for seedlings of Pinus palustris, Jackson et al. (2012) observed that field survival was not affected by the different $\mathrm{N}$ concentrations, yet, their field growth was lower at the lower concentrations.

The DQI results found on this work were much lower than those observed by Caldeira et al. (2012), which may be related to the fact that dry masses (shoot and root) and diameters also have lower values. According to Binotto et al. (2010), dry mass and collar diameter are two variables that have a strong correlation with DQI. The DQI is a good quality indicator because it considers the robustness and the balance distribution of the seedlings biomass; however, it should not be used alone to classify the seedlings quality standard (FONSECA et al., 2006).

Similar RHD results were observed in T. ciliata var. australis under different doses of OsmocotPlus, but the regression adjustment was negative quadratic (SOMAVILLA et al., 2014). For Samanea inopinata seedlings, no effect of nitrogen fertilization on the RHD was observed (FONSECA et al., 2006). According to Fonseca et al. (2002) this index should not be used alone to determine seedling quality standard. The RHD index represents the state of robustness of the plant, in that the lower the values, the more robust are the plant (LANDIS et al., 2010).

The results found in this work showed the importance to apply nitrogen fertilization on the seedling production of $T$. ciliata var. australis, doubling the size of the seedling and triplicating the dry weight. The application interval also played a major role, showing that it can reduce the time that the seedling stays in the greenhouse. The nitrogen concentration and application interval can be used in conjunction for time strategies when field planting is not possible.

\section{CONCLUSIONS}

- The application of $2060 \mathrm{mg} \mathrm{L}^{-1}$ of $\mathrm{N}$ every 7 days provides the highest growth of Toona ciliata var. australis for the development of seedlings up to 130 days after sowing.

- The absence of nitrogen and the concentration of $4000 \mathrm{mg} \mathrm{L}^{-1}$ of $\mathrm{N}$ limits the growth, regardless of the application interval.

\section{ACKNOWLEDGMENTS}

The authors are grateful to Fundação de Amparo à Pesquisa do Estado do Rio Grande do Sul (FAPERGS).

\section{REFERENCES}

AKPO, E.; STOMPH, T. J.; KOSSOU, D. K.; OMORE, A. O.; STRUIK, P. C. Effects of nursery management practices on morphological quality attributes of tree seedlings at planting: The case of oil palm (Elaeis guineensis Jacq.). Forest Ecology and Management, v. 324, p. 28 - 36, 2014.

ANTONIAZZI, A. P.; BINOTTO, B.; NEUMANN, G. M.; SAUSEN, T. L.; BUDKE, J. C. Eficiência de diferentes recipientes no desenvolvimento de mudas de Cedrela fissilis Vell. (Meliaceae). Revista Brasileira de Biociências, v. 11, p. $313-317,2013$. 
BINOTTO, A. F.; LÚCIO, A. D.; LOPES, S. J. Correlations between growth variables and the Dickson quality index in forest seedlings. Cerne, v. 16, p. 457 - 464, 2010.

BYGRAVE, F. L.; BYGRAVE, P. L. Growing australian red cedar and other meliaceae species in plantation. Canberra: Rural Industries Research and Development Corporation, 2005, 68 p.

CAIONE, G.; LANGE, A.; SCHONINGER, E. L. Crescimento de mudas de Schizolobium amazonicum (Huber ex Ducke) em substrato fertilizado com nitrogênio, fósforo e potássio. Scientia Forestalis, v. 40, p. 213 - 221 , 2012.

CALDEIRA, M. V. W.; GOMES, D. R.; GONÇALVES, E. O.; DELARMELINA, W. M.; SPERANDIO, H. V.; TRAZZI, P. A. Biossólido como substrato para produção de mudas de Toona ciliata var. australis. Revista Árvore, v. 36, p. 1009 - 1017, 2012.

FONSECA, C. A.; CRUZ, H. N. P.; GUERRERO, C. R. A. Efeito da adubação nitrogenada na produção de mudas de sete-cascas (Samanea inopinata (Harms) Ducke). Revista Árvore, v. 30, p. 537 - 546, 2006.

FONSECA, E. P.; VALÉRI, S. V.; MIGLIORANZA, E.; FONSECA, N. A. N.; COUTO, L. Padrão de qualidade de mudas de Trema micrantha (L.) Blume, produzidas sob diferentes períodos de sombreamento. Revista Árvore, v. 26, p. $515-523,2002$.

GREBNER, D. L.; BETTINGER, P.; SIRY, J. P. Introduction to forestry and natural resources. 1st. ed. London: Academic Press, 2013, 496 p.

GROSSNICKLE, S. C. Why seedlings survive: influence of plant attributes. New Forests, Dordrecht, v. 43, p. $711-738,2012$.

JACKSON, D. P.; DUMROESE, R. K.; BARNETT, J. P. Nursery response of container Pinus palustris seedlings to nitrogen supply and subsequent effects on outplanting performance. Forest Ecology and Management, v. 265, p. $1-12,2012$.

LANDIS, T. D. Mineral nutrients and fertilization. In: LANDIS TD, TINUS RW, MCDONALD SE, BARNETT JP (Ed.). The container tree nursery manual - seedling nutrition and irrigation. Washington: U.S. Department of Agriculture. 1989, p. 4-67.

LANDIS, T. D.; DUMROESE, R. K.; HAASE, D. L. The container tree nursery manual: seedling processing, storage, and outplanting. Washington: U.S. Department of Agriculture, 200 p., 2010, v. 7.

LIMA, K. B.; NETTO, A. F. R.; MARTINS, M. A.; FREITAS, M. S. M. Crescimento, acúmulo de nutrientes e fenóis totais de mudas de cedro-australiano (Toona ciliata) inoculadas com fungos micorrízicos. Ciência Florestal, v. 25, p. 853 - 862, 2015.

LISBOA, A. C.; SANTOS, P. S.; NETO, S. N. O.; CASTRO, D. N.; ABREU, A. H. M. Efeito do volume de tubetes na produção de mudas de Calophyllum brasiliense e Toona ciliata. Revista Árvore, v. 36, p. 603 - 609 , 2012 .

MELO BRAGA, M.; NETO, A. E. F.; OLIVEIRA, A. H. Influência da saturação por bases na qualidade e crescimento de mudas de cedro-australiano (Toona ciliata M. Roem var. australis). Ciência Florestal, v. 25, p. $49-58,2015$.

MORETTI, B. S.; NETO, A. E. F.; PINTO, S. I. C.; FURTINI, I. V.; MAGALHÃES, C. A. S. Crescimento e nutrição mineral de mudas de cedro australiano (Toona ciliata) sob omissão de nutrientes. Cerne, v. 17 , p. 453 463. 2011.

MORETTI, B. S.; NETO, A. E. F.; BENATTI, B. P.; PÁDUA, E. J.; SANTOS, L. L.; LACERDA, J. J. J.; DECCETTI, S. F. C. Characterization of micronutrient deficiency in australian red cedar (Toona ciliata M. Roem var. australis). International Journal of Forestry Research, v. 2012, p. 1 - 9, 2012.

PESSARAKLI, M. Handbook of Photosynthesis. 3rd ed. Florida: CRC Press, 783 p., 2016.

OLIVEIRA, R. B.; LIMA, J. S. S.; SOUZA, C. A. M.; SILVA, S. A.; FILHO, S. M. Produção de mudas de essências florestais em diferentes substratos e acompanhamento do desenvolvimento em campo. Ciência e Agrotecnologia, v. 32, n.1, p. 122 - 128, 2008

FLORESTA, Curitiba, PR, v. 49, n. 3, p. 431 - 438, jul/set 2019.

Lucchese, J. R. et.al.

ISSN eletrônico 1982-4688

DOI: $10.5380 /$ rf.v49 i3.58905 
SOMAVILlA, A.; CANTARELli, E. B.; MARIANO, L. G.; ORTIGARA, C.; LUZ, F. B. Avaliações morfológicas de mudas de Cedro australiano submetidas a diferentes doses do fertilizante osmocote plus ${ }^{\circledR}$. Comunicata Scientiae, v. 5, p. 493 - 498, 2014.

TRUBAT, R.; CORTINA, J.; VILAGROSA, A. Short-term nitrogen deprivation increases field performance in nursery seedlings of Mediterranean woody species. Journal of Arid Environments, v. 72, p. 879 - 890, 2008.

VILELA, E. S.; STEHLING, E. C. Recomendações de plantio para cedro australiano. Campo Belo: Bela Vista Florestal, 2015, 20 p.

VILLAR-SALVADOR, P.; PLANELLES, R.; ENRÍQUEZ, E.; RUBIRA, J. P. Nursery cultivation regimes, plant functional attributes, and field performance relationships in the Mediterranean oak Quercus ilex L. Forest Ecology and Management, v. 196, p. 257 - 266, 2004.

VILLAR-SALVADOR, P.; PUÉRTOLAS, J.; PEÑUELAS, J. L.; PLANELLES, R. Effect of nitrogen fertilization in the nursery on the drought and frost resistance of Mediterranean forest species. Forest Systems, v. 14, p. 408 $418,2005$.

WEBB, M. J.; REDDELL, P.; HAMBLETON, A.; MAZZA, G. M. Nutritional constraints to growth of australian red cedar (Toona ciliata) seedlings in five north Queensland soils. Australian Forestry, v. 60, p. 46 - 52, 1997. 